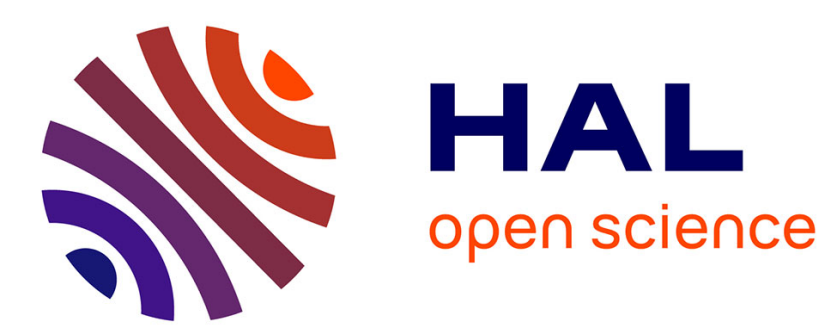

\title{
Autofluorescence of grape berries following Botrytis cinerea infection
}

M.C. Belanger, Jean-Michel Roger, Philippe Cartolaro, Marc Fermaud

\section{To cite this version:}

M.C. Belanger, Jean-Michel Roger, Philippe Cartolaro, Marc Fermaud. Autofluorescence of grape berries following Botrytis cinerea infection. International Journal of Remote Sensing, 2011, 32 (14), p. 3835 - p. 3849 . 10.1080/01431161003782064 . hal-00726170

\section{HAL Id: hal-00726170 \\ https://hal.science/hal-00726170}

Submitted on 29 Aug 2012

HAL is a multi-disciplinary open access archive for the deposit and dissemination of scientific research documents, whether they are published or not. The documents may come from teaching and research institutions in France or abroad, or from public or private research centers.
L'archive ouverte pluridisciplinaire HAL, est destinée au dépôt et à la diffusion de documents scientifiques de niveau recherche, publiés ou non, émanant des établissements d'enseignement et de recherche français ou étrangers, des laboratoires publics ou privés. 


\section{Autofluorescence of grape berries following Botrytis cinerea infection}

\section{M-C, BÉLANGER ${ }^{1}{ }^{*}$, J-M, ROGER ${ }^{1}$, P., CARTOLARO ${ }^{2}$, M., FERMAUD ${ }^{2}$}

${ }^{1}$ UMR-ITAP, Cemagref, 361, rue Jean-François Breton, B.P. 5095, Montpellier, France, 34196 , cedex 5

${ }^{2}$ UMR Santé Végétale, INRA-ENITAB, ISVV, 71, Avenue Edouard Bourlaux BP81, Villenave d'Ornon, France, 33883 cedex

$\xi$ current address: Financière agricole du Québec -Développement international, 1400, boulevard de la Rive-Sud, Saint-Romuald, Québec, G6W 8K7, Canada

Gray mold is caused by Botrytis cinerea (anamorph of an ascomycete fungus) infecting over 200 plant species worldwide and causing tremendous harvest losses in vineyards. Even though all grapevine cultivars (Vitis vinfera L.) are susceptible to the disease, defense mechanisms are induced to counteract or slow down infection and colonization by the pathogen. One of the key inducible defense molecule is resveratrol, a blue fluorescent stilbenic compound. Considering early fungal detection as a crucial step in disease control strategies, we evaluated the potential of plant fluorescence to achieve early detection of $B$. cinerea in grapevine berries. By comparing control and artificially inoculated berries, images of fluorescence were taken in the laboratory at six combinations of emission/excitation wavelengths (F440/uv, F520/uv, F690/uv, F740/uv, and F690/436-blue F740/436-blue). Data treatments include proper image correction, interest area selection, fluorescence ratios computation and edge detection. In the early stages, before 3 DAI (days post inoculation), the discrimination (of - between ?) wounded and symptomatic berries could not easily be achieved using blue fluorescence solely $(440 \mathrm{~nm})$. However, using blue out of red 
Author-produced version of the article published in International Journal of Remote Sensing, 2011, 32 (14),3835-3849. The original publicatioin is available at http://www.tandfonline.com doi:10.1080/01431161003782064

fluorescence ratio $\left(\mathrm{F}_{440} / \mathrm{F}_{740}\right)$, it was possible to detect infected berries starting as early as 4 DAI. Using image analysis and edge detection over UV-epidermal transmittance measured at $690 \mathrm{~nm}$, it was possible to detect botrytised berries as early as 6 hours after inoculation. The potential of these detection methods for use in the epidemiological field are discussed.

Key words: Bunch rot, detection, epidemiology, fluorescence, remote sensing, phytoalexins, precision viticulture, Vitis vinifera.

\section{Introduction}

Gray mold of grapevines is caused by Botrytis cinerea Pers.:Fr., the anamorph of an ascomycete fungus (Botryotinia fuckeliana Whetzel). This cosmopolitan fungus is a necrotrophic pathogen attacking over 200 plant species (Jarvis, 1980). In grapevine, it can infect leaves, in spring, where it grows in a concentric way at the margin of the blade and inflorescences which are highly susceptible, particularly dehiscent floral parts (Pezet et al. 2004). Various infection pathways have been described to establish epidemiological relationships between these first attacks, occurring early in the season, and the typical infections of maturing berries (Elmer and Michailides, 2004). Gray mold development on grape berries depends on the genetic structure of the pathogen population (Martinez et al., 2005), but is also driven by some key factors, including climatic conditions, cluster architecture and berry susceptibility (Pezet et al. 2004; Elmer and Michailides, 2004). Berry infection result mostly from i) conidia germination and penetration favored by the presence of wounds at the surface of the fruit, in particular insect injuries (Fermaud and LeMenn, 1992; Miklota et al. 2003; Holz et al. 2004), ii) mycelial spread from one berry to the next which has been associated with severe losses. Depending on climatic conditions at the end of the season, the estimated losses for French vineyards can account for up to $40 \%$ of harvest (Mathys, 1982), and the estimated grape losses due to B. cinerea represent two billions \$US 
in the world per year (Elad et al., 2004). B. cinerea can reduce drastically both yield at harvest and wine quality, for all types of white and red wines (Marchal et al, 2001, RibéreauGayon et al, 1980; Ribéreau-Gayon et al, 1998). In particular, botrytised wines are less acceptable because of mushroomy, mouldy and rotten smells even when the infection reaches low-medium levels (approx. 10\%). However, the berry infection by B.cinerea can also be desirable as 'noble rot' when present on some white grape cultivars used to produce sweet, late harvest wines (Ribéreau-Gayon et al, 1980; Ribéreau-Gayon et al, 1998). Control of gray mold in vineyards, as in various other crops, requires mostly the use of specific fungicides, but can also rely on modifications of cultivation practices (Leroux, 2004; Elmer and Michailides, 2004). The detection of $B$. cinerea can be performed by scouting in the vineyard, by using ELISA techniques (Auger et al, 1995) or by relying on forecast models, often based on climatic data (Hruby, 2003; Piéri and Fermaud, 2005; Fermaud et al., 2003). Moreover, as gray mold affects wine quality, grape sorting at harvest and/or just before the vinification process is often necessary. Sorting can be performed using polarographic measurement of oxygen consumption or by colorimetry using syringaldazin (Riberau-Gayon et al, 1998). Moreover, polyclonal and monoclonal antibody-based immunoassays have also been develop to detect B. cinerea in grape juice (Pezet et al. 2004; Elad et al., 2004). Although precise, these detection methods are time-consuming and could be improved.

During the process of grape berry infection by $B$. cinerea, various biochemical interactions take place. These interactions have been investigated thoroughly with respect to host resistance to the fungus and involve both constitutive factors and induced ones following stress or infection (Van Baarlen et al, 2004). In grapevine, the penetration of B.cinerea into the cuticle induces some defence reactions which include the synthesis by the plant of phytoalexins and pathogenesis-related (PR) proteins (Pezet et al. 2004; Miklota et al, 2003). The major phytoalexins are resveratrol and related stilbenic compounds which are induced in leaves (Langcake and McCarthy, 1979). Resveratrol can be easily observed around B. cinerea 
infection sites because of its blue fluorescence. It has been detected, $48 \mathrm{~h}$ after inoculation, at the periphery of the lesion on leaves, but not inside the colonized tissue including dead cells (Derckel et al, 1999). In grape berries, resveratrol is also produced, but partly constitutively, and accumulate in the skin only. However, resveratrol levels decrease during fruit ripening (Van Baarlen et al, 2004). It is generally assumed that $B$. cinerea must detoxify the stilbenic compounds, particularly resveratrol and the highly fungitoxic pterostilbene, in order to colonize grapevine (Pezet et al, 2004; Schouten et al. 2002). Laccases are inducible phenoloxidizing enzymes catalyzing the oxidation of phenolic substrates (blue-copper oxidases) which are considered to play a major role in the degradation of the stilbenic compounds by the fungus. Other biochemical interactions, different from those involving defence reaction mechanisms, have also been reported. Karavaev \& Polyakova (2000) showed a decrease in the content of chlorophyll in leaves infected with B. cinerea and Berger et al. (2004) observed an increased photosynthetic activity in the surroundings of a B.cinerea lesion on tomato leaves. Such a decrease in chlorophyll content and changes in photosynthetic activity have also been observed on corn plants (McMurtrey et al. 1994). Therefore, it may be assumed that such modifications could also be detectable using plant fluorescence on grape berries. Considering all these host-pathogen interactions, particularly the host defence reactions even if B.cinerea does not trigger systemic acquired resistance (Elad et al., 2004), we have hypothesized that it would be possible to rapidly detect $B$. cinerea on grape berries using remotely sensed fluorescence.

In our study, we have evaluated the autofluorescence response of mature grape berries to $B$. cinerea infection in controlled conditions and its potential to achieve early detection. To do so, we collected fluorescence images on infected and control berries. We performed standard plant fluorescence ratios analysis as well as image analysis using edge detection algorithm. 


\section{Material and Methods}

\section{Grape berries}

Mature grape bunches (Vitis vinifera) of the white cv. Italia, of 500, 550 and $660 \mathrm{~g}$ were used in experiments $A, B$, and $C$, respectively. Ten, randomly selected grape berries were detached from each bunch by cutting the pedicel from the main stalk using a fire-sterilised utility knife. Each berry was surface-sterilized by immersion in $95 \%$ denaturated ethyl alcohol for $30 \mathrm{sec}$. They were then soaked and rinsed thoroughly using demineralised water.

\section{Artificial inoculations}

The B. cinerea strain 234, belonging to the transposa genetic type (Group-II), was used because strains of this type are more aggressive on grape berries than vacuma Group-II strains (Martinez et al, 2005). Provided by UMR Santé végétale (INRA-ENITA, Bordeaux, France), a detailed phenotype of this isolate has been described by Martinez et al (2003). This isolate was obtained originally in 1998, at harvest, in a Bordeaux vineyard (Pessac-Léognan) from mature white berries (cv. Sémillon blanc). Pure cultures were grown in Petri dishes on 1.5\% malt agar solid medium (Biokar Diagnostic, Beauvais, France).

In order to inoculate, mycelial plugs ( $4 \mathrm{~mm}$ in diameter) were taken, using a fire-sterilised punch, from pure cultures on malt agar plates incubated at $20^{\circ} \mathrm{C}$ (the inoculum was transplanted to a new malt agar Petri dish on 09/18/2006). Before inoculating, the skin of all berries was pierced using a fire-sterilized needle. The needle was sterilized again and used to place one inoculum plug per berry, exactly at the point of skin piercing (applying the disc with mycelium facing the berry skin). Five berries were inoculated on October $10^{\text {th }}$ (Experiment A), five on October $18^{\text {th }}$ (Experiment B) and five on November $2^{\text {nd }}$ (exp. C). As a control, for each experiment, the five remaining berries were inoculated with a virgin malt agar disc applied exactly at the point of skin piercing. The berries were then installed on a metallic netting in a plastic box (humid chamber $(20 \mathrm{x} 15 \mathrm{~cm} \times 5)$. To ensure a high humidity 
atmosphere, a moist sterile gauze was installed underneath the metallic netting. The humid chamber was kept in the laboratory, at room temperature (approx. $21^{\circ} \mathrm{C}$ ) under natural daylight. The incubation period corresponded to the time between the inoculation and the first fluorescence measurements, i.e. 3, 2, and 0.25 days for experiment $A, B$, and $C$, respectively.

\section{Fluorescence measurements}

Fluorescence measurements were performed exactly $3 \& 6$ days after inoculation (DAI) for experiment $A, 2 \& 5$ DAI for experiment $B$, and $0.25,1,4, \& 6$ DAI for experiment $C$. Fluorescence measurements were realized using an imaging fluorometer as described in Belzile et al., (2003). The FLIM-100 imaging fluorometer used an interline CCD camera (CoolSnapHQ, RoperScientific, AZ, USA) modified for on-chip accumulation capability. The fluorescence was induced by a xenon flash lamp source (Hamamatsu, NJ, USA) producing intense light pulses at $50 \mathrm{~Hz}$ repetition rate (4 $\mu$ s pulse width) using a pulse generator (model 500B Berkeley Nucleonics Corporation, CA, USA). For plant leaf fluorescence applications, UV (360 $\pm 40 \mathrm{~nm})$ and Blue $(436 \pm 20 \mathrm{~nm})$ excitation wavelengths were selected using band pass filter (Chroma Technology Corp., VT, USA). The excitation pulses were synchronized with camera acquisition using proper electronics and control software developed by Telops, Quebec, Canada. Image acquisition for each light pulse was done using $5 \mu$ s integration time. Charges were accumulated on a CCD side layer. The charges were transferred to the frame grabber at the end of image acquisition process. This system enabled gated detection of low light level signal without using an image intensifier. Fluorescence imaging requires between 75 to 2500 acquisitions depending on the sample and on detected wavelength. Four narrow band pass filters (CVI Laser, NM, USA) were placed in front of the camera allowing precise detection of 440,520, 690 and $740 \pm 10 \mathrm{~nm}$ fluorescence. UV-induced fluorescence was measured at the four emission bands whereas blue-induced fluorescence intensities were measured at 690 and $740 \mathrm{~nm}$. 
Author-produced version of the article published in International Journal of Remote Sensing, 2011, 32 (14),3835-3849. The original publicatioin is available at http://www.tandfonline.com doi:10.1080/01431161003782064

Lastly, for the fluorescence measurements, the grape berries were extracted from the plastic box using a pair of pliers rinsed thoroughly in $95 \%$ denaturated ethyl alcohol (beforehand and between each measurement). Grape berries were $50 \mathrm{~cm}$ away from the excitation source, thus effective excitation area was approximately $20 \mathrm{~cm}^{2}$. All fluorescent measurements were done in the dark.

\section{Image and data analysis}

After proper image correction (Belanger et al, accepted), including for example corrections for the number of acquisitions, the transmittance of the filters and the sensitivity of the camera, we conducted image analysis and data treatment as summarized schematically in figure 1. For all fluorescence images, a mask was delineated manually to determine the berry area and exclude non-berry pixels for subsequent data treatment. Fluorescence ratios for each berry pixel were computed. The fluorescence ratios computed were F440/F520, F440/F690, F440/F740, F520/F690, F520/F740, F690/F740, all induced by a UV light source, and UV epidermal transmittance measured at $690 \mathrm{~nm}$ (ET690) and at $740 \mathrm{~nm}$ (ET740) [Eq.1] induced by UV and blue light sources (Bilger et al. 1997).

$$
E T_{\lambda}=F_{\lambda U V} / F_{\lambda b l u e}
$$

where $\lambda=$ the selected wavelength, either $690 \mathrm{~nm}$ or $740 \mathrm{~nm}$

$F_{\lambda U V}$ is the UV-induced fluorescence detected at $\lambda=690 \mathrm{~nm}$ or $740 \mathrm{~nm}$

and $F_{\lambda b l u e}$ is the blue-induced fluorescence detected at $\lambda=690 \mathrm{~nm}$ or $740 \mathrm{~nm}$

Once the fluorescence ratios were computed and the mask outlined, we computed the spatial average for each grape berry, resulting in one value per berry for each ratio and at each date of measurements. These values (or transformed ones when necessary) were used for the computation of the analysis of variance (ANOVA). Parameters presenting heterogeneous variances were transformed using a logarithmic, square root or Box-Cox transformation 
(Peltier, 1998). The completely randomized ANOVA calculations were performed using the glm procedure from the SAS software (SAS Institute, NC, USA).

An edge detection algorithm was also conducted on each ratio image using the canny algorithm in the Image processing toolbox of Matlab (The Matworks, v 7.0). The canny algorithm sets up two different thresholds in order to detect strong and weak edges, and includes the weak edges in the output only if they are connected to strong edges. For each image, we extracted the number of edge pixels and we computed an ANOVA on this parameter using the SAS software as described above.

\section{Results and discussion}

\section{Gray mold development and incidence on grape berries}

Because the malt agar inoculum plug showed a strong fluorescence at $440 \mathrm{~nm}$, it was removed from the surface of both inoculated and control berries before the first fluorescence measurements, i.e. 3,2 and 0.25 days after inoculation in the experiment $\mathrm{A}, \mathrm{B}$, and $\mathrm{C}$, respectively. Consequently the visible development rate of $B$. cinerea was influenced by the inoculation period. For experiment $C$, the inoculum plug remained only 6 hours on the berries resulting in a slower B. cinerea colonization than in experiments A and B. For experiment A, six days after inoculation (6 DAI), all five berries expressed typical symptoms of gray mold. The corresponding digital images of control and symptomatic berries (Figure 2) showed i) on control berries, a circular scar darker and slightly bigger than the needle diameter; ii) on infected berries, a colonization process leading to a brown, rotted lesion surrounding a berry splitting from which exudates were leaking. On control berries, such a scar may include lignificated tissue as well as plant phenolic compounds (GonzalezBarrio et al., 2005; Elad et al., 2004). For experiment B, at 5 DAI, 4 out of 5 inoculated berries developed symptoms of gray mold. In experiment $\mathrm{C}$, four days after inoculation, typical B. cinerea symptoms expressed on all 5 inoculated berries. When compared with 
Author-produced version of the article published in International Journal of Remote Sensing, 2011, 32 (14),3835-3849. The original publicatioin is available at http://www.tandfonline.com doi:10.1080/01431161003782064

control berries, Botrytised berries in this last experiment were characterized by a deeper berry split and a larger area of lignificated tissue surrounding the split area.

\section{Fluorescence data based on spatial average over the berry area}

A preliminary result was obtained by comparing Red-Green-Blue (RGB) images of grape berries under visible light (Fig 3a) and under long wavelength UV radiation (360 nm) (Fig $3 b)$. On figure $3 b$, a strong blue fluorescence around the contaminated area was noticeable on the inoculated berry (Exp. C, 6 DAI). The fluorescence distribution, associated with a spreading lesion caused by $B$. cinerea, was consistent with observations on infected detached grapevine leaves (Langcake and McCarthy, 1979). The rotted area was surrounded by a band of blue fluorescence due to the presence of resveratrol in an apparently healthy zone of tissue up to $5 \mathrm{~mm}$ in advance of the visibly rotted area (Langcake and McCarthy, 1979). However, on the control berry, a blue fluorescence was also detected clearly, although restricted at the wounded site (Fig 3b). Therefore, this could mislead a detection based on blue fluorescence solely.

In table 1 are summarized the fluorescence ratios calculated from the fluorescence images based on a spatial average over the berry area. The earlier detection made using fluorescence ratios was achieved at 3 DAI in experiment $\mathrm{A}$. By using $\mathrm{F}_{520} / \mathrm{F}_{690}$ or $\mathrm{F}_{520} / \mathrm{F}_{740}$, the differences between control and infected berries were significant at $P=0.05$. By considering a significant result in all three experiments, the best detection was provided using $\mathrm{F}_{440} / \mathrm{F}_{740}$ which increased in botrytised berries when compared to control ones. The earliest detection made using this fluorescence ratio was achieved at 4 DAI in experiment C. Ariana et al (2006) also observed an increase in $\mathrm{F}_{440} / \mathrm{F}_{740}$ for black rot tissue on apples compared to healthy ones. Fluorescence ratios not involving blue-green fluorescence (from $440 \mathrm{~nm}$ to $520 \mathrm{~nm}$ ) did not achieve successful detection of Botrytis using a spatial average over the berry area. 
Furthermore, it was noticeable that the results calculated with $\mathrm{F}_{440}$ as the numerator showed, most often, significant $(P=0.05)$ differences between control and infected berries, i.e. in two or three of the experiments (Table 1). By looking at $\mathrm{F}_{440}$ fluorescence images (Fig. 4), it was detected on the control berries that the wound fluoresced. This was presumably due to the healing process, involving lignification and accumulation of plant phenolics at the point of wounding, because mechanical wounding in plants can induce rapid activation of genes that are involved in healing and defense against pathogens (Bowles, 1991). Such compounds fluoresce at $440 \mathrm{~nm}$ when exposed to UV-light (Machado et al., 2001). Furthermore and although the capacity of berries to synthetize resveratrol decreases during ripening, stilbenic compounds should also be induced by the mechanical wounding in grape berries as also shown in leaves (Blaich and Bachmann, 1980; Bavaresco et al., 1997; Pezet et al, 2004). Furthermore, it was noticeable that the fluorescent area was almost constant in size and shape in control berries, whereas it was evolving in the infected ones. However, the central area within the developing lesion was no longer fluorescing at $440 \mathrm{~nm}$ when observed at 3,4 or 6 DAI. This could be due to the fact that $B$. cinerea produces various extracellular enzymes to colonize berries, particularly laccases that can have digested plant phenolics, particularly the stilbenic compounds, originally present in the inner part of the expanding lesion (Sbaghi et al., 1996; Van Baarlen et al, 2004). The boundary of the colonized lesion showed a higher $\mathrm{F}_{440}$ intensity resulting presumably from the induction of defence mechanisms activated by the berry following $B$. cinerea infection and colonization. All these observations were totally in agreement with the results on grapevine leaves infected by B. cinerea (Derckel et al, 1999). Once under a Botrytis attack, the plant reallocates some polyphenols, such as resveratrol and associated stilbenic oligomers, at the point of infection (Langcake and McCarthy, 1979; Pezet et al. 2004). Thus, fluorescence observed at $440 \mathrm{~nm}$ clearly showed the colonized area by $B$. cinerea, but in the early infection stages (before $3 \mathrm{DAI}$ ), it can not be easily discriminated from any wound the berry might suffer (mechanical, insects, for instance). 
Author-produced version of the article published in International Journal of Remote Sensing, 2011, 32 (14),3835-3849. The original publicatioin is available at http://www.tandfonline.com doi:10.1080/01431161003782064

Fluorescence data based on edge detection

Examples of earliest images of edge detection performed on UV-epidermal transmittance (ET690) are shown in Figure 5. In both experiments $\mathrm{A}$ and $\mathrm{C}$, it was possible to detect exclusively the infected area when compared to (with ?) control berries. On control berries, the mechanical wound was not detected and no fluorescence pattern was observed, except for the berry surroundings only.

In Table 2, the proportion of edges detected from the fluorescence images was compared to the total berry area (evaluated by the mask delineation). In experiments $\mathrm{A}$ and $\mathrm{C}$, but not in experiment $\mathrm{B}$, infected berries showed a significantly $(P=0.05)$ lower proportion of edges detected than control berries. The results based on ET690 showed significant $(P=0.05)$ differences which were detected at early dates of assessment, i.e. 3 and 1 DAI in experiments A and C, respectively. As for inoculated berries, the Botrytis-colonized area at the surface of the berry was easily detected by an increase in ET690. In experiment $\mathrm{C}$, the deincrease in ET690[U1], associated with the Botrytis-colonized area, was detected as early as 6 hours after inoculation and was significant at $P=0.1$. To account for this increase (decrease ?) in UVepidermal transmittance (ET690),[U2] it can be hypothesized that UV-absorbing compounds were catalyzed by laccases during the infection process enabling higher amount of UV-light getting[U3] to chlorophyll. A similar mechanism was suggested to interpret a decrease in ET690 measured on crop leaf following nitrogen deficiency (Samson et al., 2000. The reduction of UV-induced chlorophyll fluorescence, compared to blue-induced chlorophyll fluorescence, was attributed to an accumulation of UV-absorbing secondary metabolites in the leaf. .

NB : Karavaev \& Polyakova (2000) showed a decrease in the content of chlorophyll in leaves infected with B. cinerea. Est ce une info incorporable ici en discussion? 


\section{Conclusion}

In this study we evaluated the autofluorescence response of grape berries to a $B$. cinerea infection. Under UV-light, it was possible to detect the blue fluorescence of accumulated resveratrol and associated stilbenic compounds (Langcake and McCarthy, 1979; Pezet et al. 2004; van Baarlen et al. 2004). Although a strong signal, this blue fluorescence can be confounded with the fluorescence surrounding any mechanical wound on the berry. Some defence mechanisms, particularly the production by the berry of stilbenic phytoalexins, are not specific and can be activated by biotic as well as abiotic stresses? (e.g. hail, insects ...) (Blaich and Bachmann, 1980; Bavaresco et al., 1997; Pezet et al. 2004; van Baarlen et al. 2004). This can be misleading in natural conditions, particularly in vineyards where insect injuries are associated with B. cinerea development on berries (Fermaud and Le Menn, 1992; Holz et al. 2004). Thus, by using measures of UV-induced fluorescence at $440 \mathrm{~nm}$ solely, the discrimination between wounded and botrytised berries could not be easily achieved. However, other interesting results based on UV-induced fluorescence measurements, such as the ratio $\mathrm{F}_{440} / \mathrm{F}_{740}$, could eventually be used in a handheld device. According to our results and using a spatial average of $\mathrm{F}_{440} / \mathrm{F}_{740}$ over the berry area, the detection of berries infected by the fungus could be achieved starting as soon as 4 Days After Inoculation (DAI). The designed instrument should acquire UV-induced $\mathrm{F}_{440}$ and $\mathrm{F}_{740}$ fluorescence in a fast and efficient way. Further studies are already initiated by Cemagref (UMR ITAP), Montpellier, on a prototype built using LED, filters and photodiodes. If it can be implemented directly in the field, the detection of gray mold lesions as soon as 4 days after infection (DAI) can be considered as an early detection. Such a delay in detection would allow potential applications to be developed either i) in the vineyard, during the season, to improve control strategies and/or ii) at the beginning of the wine making process, to sort infected berries from healthy ones. In the field, the disease can be expressed on maturing berries during 1 or 2 months between the veraison stage and harvest, following a possible period of latency in the 
Author-produced version of the article published in International Journal of Remote Sensing, 2011, 32 (14),3835-3849. The original publicatioin is available at http://www.tandfonline.com doi:10.1080/01431161003782064

herbaceous berries (Pezet et al, 2004). The visual detection of infected berries at or just after the veraison stage has to be improved, especially on black cultivars, because the early symptoms are not easily distinguished and a long incubation period is associated with these relatively resistant tissues (Elmer and Michailides, 2004). However, a delay in the detection should also be considered because the initial infectious foci develop often within the grape cluster and have to expand to the outer berries to become visible and easily detectable (Holz et al. 2004; Miklota et al., 2003). Furthermore, our results may be useful to implement a more precise detection method at the beginning of the wine making process, when bunches are exposed individually on sorting tables. It can be assumed that fluorescence ratios, which were computed as spatial average over an area, or image analysis based on UV-epidermal transmittance (ET690) would be more rapid and adapted than visual assessments. The latter method could be more powerful than fluorescence ratios allowing berries recently rotted by $B$. cinerea to be detected as early as 1 day after infection.

\section{Acknowledgements}

The authors wish to thank Dr. Alain A. Viau from the Agricultural and Applied Geomatic (GAAP) laboratory in Québec, Canada for the access to fluorescence instruments and J. ROUDET (UMR Santé végétale, Bordeaux) for technical assistance. 


\section{References}

Abreu, C.G., Carvalho, L., Gaspar, M.J., Gomes, A.L., Colaço, J. and Cardoso, A.O. 1999. Assessment of resistance to chestnut ink disease. Acta Hort. (ISHS) 494:363-368 http://www.actahort.org/books/494/494_55.htm

Ariana, D., Guyer, D.E., and Shrestha, B. 2006. Integrating multispectral reflectance and fluorescence imaging for defect detection on apples. Computers and electronics in agriculture $50: 148-161$.

Auger, J.S., Esterio, M.G., and Munoz, F.M.A. 1995. Immunodetection and quantification assays of Botrytis cinerea on table grape. Fitopatologia 30:148-159.

Bavaresco L., Petegolli, D., Cantu, E., Fregoni, M., Chiusa, G., Trevisan, M. 1997. Elicitation and accumulation of stilbene phytoalexins in grapevine berries by Botrytis cinerea. Vitis 36 : $77-83$.

Bélanger, M-C., Roger, J-M., Cartolaro, P., Viau, A.A., and Bellon-Maurel, V. (submitted 0831-2006). Detection of powdery mildew in grapevine using remotely-sensed UV-induced fluorescence. International Journal of Remote Sensing.

Belzile, C., Bélanger, M.-C., Viau, A.A., Chamberland, M., and Roy, S. 2003. An operational system for crop assessment, p. 244-252, In B. S. Bennedsen, ed. Proceedings of Photonic East conference: Monitoring Food Safety, Agriculture, and Plant Health, Vol. 5271. SPIE, Providence, RI. 
Author-produced version of the article published in International Journal of Remote Sensing, 2011, 32 (14),3835-3849. The original publicatioin is available at http://www.tandfonline.com doi:10.1080/01431161003782064

Berger, S., Papadopoulos, M., Schreiber, U., Kaiser, W., and Roitsh, T. 2004. Complex regulation of gene expression, photosynthesis and sugar levels by pathogen infection in tomato. Physiologia plantarum 122:419-428.

Bilger, W., Veit, M., Schreiber, L., and Schreiber, U. 1997. Measurement of leaf epidermal transmittance of UV radiation by chlorophyll fluorescence. Physiologia plantarum 101:754763.

Blaich R., and Bachmann O. 1980. The resveratrol synthesis in Vitaceae: induction and cytological observations. Vitis, 19, 230-240.

Bowles, D. 1991. The wound response of plants. Curr. Biol. 1, 165-167.

Derckel, J.-P., Baillieul, F., Manteau, S., Audran, J.-C., Haye, B., Lambert, B., and Legendre, L. 1999. Differential induction of grapevine defenses by two strains of Botrytis cinerea. Phytopathology 89:197-203.

Elad, Y., Williamson, B., Tudzynski, P., and Delen, N., (eds.) 2004. Botrytis: Biology, pathology and control, pp. 1-428. Kluwer Academic Publishers, Dordrecht.

Elmer, P., Michailides, T.J., 2004. Epidemiology of Botrytis cinerea in orchard and vine crops. In: Botrytis: biology, pathology and control. Elad Y. et al (Eds). Pp.195-222. Kluwer Acad. Publishers, Dordrecht. 
Author-produced version of the article published in International Journal of Remote Sensing, 2011, 32 (14),3835-3849. The original publicatioin is available at http://www.tandfonline.com doi:10.1080/01431161003782064

Fermaud, M., and Le Menn. 1992. Transmission of Botrytis cinerea to grape by grape berry moth larvae. Phytopathology 82, 1393: 1398

Fermaud M., Piéri P. and Mimiague F. 2003. Precursory climatic indices of Botrytis rot development in mature grapes. IOBC/WPRS Bulletin "Integrated Protection in Viticulture" C. Lozzia Ed., 26 (8) : 63-67.

Gonzalez-Barrio, R., Salmenkallio-Marttila, M., Tomas-Barberan, F.A., Cantos, E., and Espin, J.C. 2005. Etiology of UV-C-induced browning in Var. Superior white table grapes. Journal of agricultural and food chemistry 53:5990-5996.

Holz, G., Coertze, S., and Williamson, B. 2004. The ecology of Botrytis on plant surface, pp. 9-27 In Botrytis: biology, pathology and control. Elad Y. et al (Eds). Pp.195-222. Kluwer Acad. Publishers, Dordrecht.

Hruby, R. 2003. Early warning system for grapevine in South Moravia (Czech Republic). Bulletin OEPP/EPPO Bulletin 33:433-436.

Jarvis, W.R. 1980 Epidemiology. P.219-250 In The biology of Botrytis. J.R” Coley-Smith, K. Verhoeff, and W.R. Jarvis, Eds. Academic Press, New York.

Karavaev, V., and Polyakova, I. 2000. Slow fluorescence induction and photosynthesis in bean and cabbage leaves infected by Botrytis cinerea XIIth International Botrytis symposium, Reims, France.

Langcake, P. and McCarthy, W.V. 1979. The relationship of resveratrol production to infection of grapevine leaves by Botrytis cinerea. Vitis, vol. 18, pp.244-253. 
Author-produced version of the article published in International Journal of Remote Sensing, 2011, 32 (14),3835-3849. The original publicatioin is available at http://www.tandfonline.com doi:10.1080/01431161003782064

Leroux, P. 2004. Chemical control of Botrytis and its resistance to chemical fungicides. P. 195-217 In Botrytis: biology, pathology and control. Elad Y. et al (Eds). Pp.195-222. Kluwer Acad. Publishers, Dordrecht.

Machado, A.E.H., Nicodem, D.E., Ruggiero, R., da S Perez, D., and Castellan, A. 2001. The use of fluorescent probes in the characterization of lignin: the distribution, by energy, of fluorophores in Eucalyptus grandis lignin. Journal of photochemistry and photobiology 138:253-259.

Marchal, R., Tabary, I., Valade, M., Moncomble, D., Viaux, L., Robillard, B., and Jeandet, J. 2001. Effects of Botrytis cinerea infection on Champagne wine foaming properties. Journal of the science of food and agriculture 81:1371-1378.

Martinez, F., Blancard, D., Lecomte, P. Levis, C., Dubos, B., and Fermaud, M. 2003. Phenotypic differences between vacuma and transpose subpopulations of Botrytis cinerea. Eur. J. Plant Pathol. 109 (5): 479-488.

Martinez, F., Dubos, B., and Fermaud, M. 2005. The role of saprotrophy and virulence in the population dynamics of Botrytis cinerea in the vineyards. Phytopathology 95, 692-700.

Mathys, G. 1982. Importance économique de la pourriture grise de la vigne, p. 3-14 Symposium international consacré à la pourriture grise de la vigne, Vol. 12. Bulletin OEPP, Colmar (France).

McMurtrey, J.E., Chappelle, E.W., Kim, M.S., Meisinger, J.J., and Corp, L.A. 1994. Distinguishing nitrogen fertilization levels in field corn (Zea mays, L.) with actively induced 
Author-produced version of the article published in International Journal of Remote Sensing, 2011, 32 (14),3835-3849. The original publicatioin is available at http://www.tandfonline.com doi:10.1080/01431161003782064

fluorescence and passive reflectance measurements. Remote Sensing of Environment, vol.47, pp. 36-44.

Miklota-Gabler, F.M., Smilanick, J.L., Mansour, M., Ramming, D.W., and Mackey, B.E. 2003. Correlation of morphological, anatomical, and chemical features of grape berries with resistance to Botrytis cinerea. Phytopathology 93:1263-1273.

Pezet, R., Viret, O., Gindro, K. 2004. Plant microbe interaction: the Botrytis gray mold of grapes. Biology, biochemistry epidemiology and control management. In advances in Plant Physiology, vol. 7. Hemantaranjan, A. (ed.) Varanasi 221005, India, pp. 75-120.

Peltier, M.R., Wilcox, C.J. and Sharp, D.C., 1998. Technical Note: Application of the BoxCox Data Transformation to animal science experiments. Journal of animal science $76847-$ 849.

Piéri P. and Fermaud M., 2005. Effects of defoliation on temperature and wetness of grapevine berries. Acta Horticulturae (ISHS) 689: 109-116.

Riberau-Gayon, P., Dubourdieu, D., Dionèche, B., and Lonvaud, A. 1998. Traité d'oenologie 1. Microbiologie du vin et vinifications. 2nd ed., Paris.

Ribéreau-Gayon, J., Ribéreau-Gayon, P., and Séguin G. 1980. Botrytis cinerea in enology. Pp. 251-274. In The biology of Botrytis J.R. Coley-Smith et al (Eds). Academic Press, New York. 318 p.

Samson, G., Tremblay, N., Dudelzak, A.E., Babichenko, S.M., Dextrase, L. and Wollring, J., 2000. Nutrient stress of corn plants: early detection and discrimination using a compact 
Author-produced version of the article published in International Journal of Remote Sensing, 2011, 32 (14),3835-3849. The original publicatioin is available at http://www.tandfonline.com doi:10.1080/01431161003782064

multiwavelength fluorescent lidar, p. 214-223 4th EARSeL Workshop Lidar Remote Sensing of Land and Sea, Vol. 1, Dresden, Germany.

SAS, 1999. SAS/STAT User's Guide, The GLM Procedure. [Online] Available by SAS Institue at http://v8doc.sas.com/sashtml/

Sbaghi M., Jeandet, P., Bessis, R., Leroux, P. 1996. Degradation of stilbene-type phytoalexins in relation to the pathogenicity of Botrytis cinerea to grapevine. Plant Pathol. 45: 139-144.

Schouten, A., Wagemakers, L., Stefanato, F.L., van der Kaaij, R.M., and van Kan, J.A.L. 2002. Resveratrol acts as a natural profungicide and induces self-intoxication by a specific laccase. Molecular Microbiology 43:883-894.

Van Baarlen, P., Legendre, L., and van Kan, J. 2004. Plant defence compounds against Botrytis infection. Pp. 143-155. In Botrytis: biology, pathology and control. Elad Y. et al (Eds). $\quad$ Pp.195-222. Kluwer Acad. Publishers, Dordrecht. 
Author-produced version of the article published in International Journal of Remote Sensing, 2011, 32 (14),3835-3849. The original publicatioin is available at http://www.tandfonline.com doi:10.1080/01431161003782064

Table 1: Means of spatial average for each fluorescence ratio for control and infected berries in the three experiments (A, B and C) taken at (on ?) different dates post inoculation.

\begin{tabular}{|c|c|c|c|c|c|c|c|c|}
\hline \multirow{2}{*}{$\begin{array}{r}\text { Ratio } \\
\text { Date of } \\
\text { measure }\end{array}$} & \multicolumn{2}{|c|}{ Experiment A } & \multicolumn{2}{|c|}{ Experiment B } & \multicolumn{4}{|c|}{ Experiment $\mathrm{C}$} \\
\hline & $3 \mathrm{DAI}$ & $6 \mathrm{DAI}$ & $2 \mathrm{DAI}$ & $5 \mathrm{DAI}$ & $0.25 \mathrm{DAI}$ & $1 \mathrm{DAI}$ & 4 DAI & $6 \mathrm{DAI}$ \\
\hline \multicolumn{9}{|l|}{$\mathbf{F}_{440} / \mathbf{F}_{520}$} \\
\hline Control & 0.5756 & 0.5380 & 0.4485 & 0.4516 & 0.5249 & 0.5359 & 0.5498 & 0.7274 \\
\hline Botrytis & 0.6161 & $0.8167 * * *$ & 0.4658 & $0.5323 *$ & 0.5183 & 0.5191 & $0.6451 * *$ & $0.5559 * * *$ \\
\hline \multicolumn{9}{|l|}{$F_{440} / F_{690}$} \\
\hline Control & 0.3663 & 0.3621 & 0.1653 & 0.1803 & 0.3199 & 0.3543 & 0.3473 & 0.3062 \\
\hline Botrytis & 0.3305 & 0.3647 & 0.1825 & $0.2493 * *$ & 0.3032 & 0.3392 & $0.6088 * *$ & $0.5687 * *$ \\
\hline \multicolumn{9}{|l|}{$\mathbf{F}_{440} / \mathbf{F}_{740}$} \\
\hline Control & 0.2403 & 0.2456 & 0.3890 & 0.4323 & 0.6475 & 0.7497 & 0.7641 & 0.7512 \\
\hline Botrytis & $0.4752 *$ & $1.8437 * * *$ & 0.4258 & $0.6066 * * *$ & 0.6361 & 0.7217 & $1.3431 * *$ & $1.3862 *$ \\
\hline \multicolumn{9}{|l|}{$\mathbf{F}_{520} / \mathbf{F}_{690}$} \\
\hline Control & 0.1321 & 0.1561 & 0.3796 & 0.4046 & 0.8319 & 0.8347 & 0.7721 & 0.7639 \\
\hline Botrytis & $0.2164 * *$ & $0.4416 * * *$ & 0.3930 & 0.4273 & 0.8331 & 0.8331 & $0.9291 * * *$ & $0.9002 * *$ \\
\hline \multicolumn{9}{|l|}{$\mathbf{F}_{520} / \mathbf{F}_{740}$} \\
\hline Control & 0.8898 & 1.0051 & 0.8901 & 0.9698 & 1.4959 & 1.4769 & 1.4537 & 1.4413 \\
\hline Botrytis & $1.3712 * *$ & $2.5876 * * *$ & 0.9068 & 1.0370 & 1.5079 & 1.5074 & 1.3162 & $1.1218 * *$ \\
\hline \multicolumn{9}{|l|}{$\mathbf{F}_{690} / \mathbf{F}_{740}$} \\
\hline Control & 2.3114 & 2.2626 & 2.3570 & 2.4083 & 2.0370 & 2.1276 & 2.2144 & 2.4728 \\
\hline Botrytis & 2.2804 & 2.2115 & 2.3201 & 2.4844 & 2.1312 & 2.1588 & 2.2166 & 2.4020 \\
\hline \multicolumn{9}{|l|}{$\mathbf{E T}_{690}$} \\
\hline Control & 0.1757 & 0.1822 & 0.1552 & 0.1616 & 0.2020 & 0.1872 & 0.1932 & 0.1992 \\
\hline Botrytis & 0.1991 & 0.1919 & 0.1648 & 0.2016 * & 0.1946 & 0.2054 & 0.2036 & 0.2378 \\
\hline \multicolumn{9}{|l|}{$\mathbf{E T}_{740}$} \\
\hline Control & 0.1938 & 0.1962 & 0.1739 & 0.1731 & 0.2192 & 0.1968 & 0.2042 & 0.1985 \\
\hline Botrytis & 0.2060 & 0.2096 & 0.1866 & 0.2078 * & 0.2072 & 0.2142 & 0.2160 & 0.2007 \\
\hline
\end{tabular}

Where DAI=Days after inoculation

$*, * *, * * *$ : significant at $P \leq 0.1,0.05,0.01$, respectively 
Author-produced version of the article published in International Journal of Remote Sensing, 2011, 32 (14),3835-3849. The original publicatioin is available at http://www.tandfonline.com doi:10.1080/01431161003782064

Table 2: Means of edge proportion (\%) detected for each fluorescence ratio for the three treatments, taken at different dates, for $\exp A, B$, and $C$ data.

\begin{tabular}{|c|c|c|c|c|c|c|c|c|}
\hline \multirow{2}{*}{$\begin{array}{l}{[\mathrm{U} 4] \text { Edge }} \\
\text { proportion } \\
\text { Date of } \\
\text { measure }\end{array}$} & \multicolumn{2}{|c|}{ Experiment A } & \multicolumn{2}{|c|}{ Experiment B } & \multicolumn{4}{|c|}{ Experiment $\mathrm{C}$} \\
\hline & 3 DAI & 6 DAI & $2 \mathrm{DAI}$ & $5 \mathrm{DAI}$ & $0.25 \mathrm{DAI}$ & $1 \mathrm{DAI}$ & $4 \mathrm{DAI}$ & $6 \mathrm{DAI}$ \\
\hline \multicolumn{9}{|l|}{$\mathbf{F}_{440} / \mathbf{F}_{520}$} \\
\hline Control & 15.79 & 13.96 & 15.62 & 15.39 & 17.57 & 16.84 & 14.17 & 15.87 \\
\hline Botrytis & 14.17 * & $16.09 * *$ & 15.72 & 15.27 & 13.69 & 13.58 & 13.21 & $11.82 * *$ \\
\hline \multicolumn{9}{|l|}{$F_{440} / F_{690}$} \\
\hline Control & 12.71 & 14.01 & 12.26 & 11.86 & 15.89 & 15.86 & 11.38 & 13.92 \\
\hline Botrytis & 11.74 & $11.78 * *$ & 14.71 & 12.93 & 12.41 & 12.55 & 11.74 & $10.79 * * *$ \\
\hline \multicolumn{9}{|l|}{$\mathbf{F}_{440} / \mathbf{F}_{740}$} \\
\hline Control & 15.03 & 15.75 & 14.56 & 13.87 & 18.12 & 17.69 & 14.39 & 14.01 \\
\hline Botrytis & $12.48 * *$ & $12.15 * * *$ & 15.90 & 13.46 & $15.01 *$ & 15.13 & 14.24 & 12.46 \\
\hline \multicolumn{9}{|l|}{$\mathbf{F}_{520} / \mathbf{F}_{690}$} \\
\hline Control & 15.90 & 16.46 & 16.94 & 16.63 & 15.81 & 15.90 & 15.78 & 15.63 \\
\hline Botrytis & $15.03 * *$ & $13.43 * * *$ & 16.74 & 15.01 & 15.41 & 15.88 & 15.29 & 14.09 * \\
\hline \multicolumn{9}{|l|}{$\mathbf{F}_{520} / \mathbf{F}_{740}$} \\
\hline Control & 17.76 & 18.20 & 17.29 & 17.68 & 18.78 & 18.37 & 18.03 & 14.77 \\
\hline Botrytis & $16.34 * *$ & $14.49 * * *$ & 17.78 & 16.02 & 18.15 & 18.15 & 17.11 & 14.80 \\
\hline \multicolumn{9}{|l|}{$\mathbf{F}_{690} / \mathbf{F}_{740}$} \\
\hline Control & 21.09 & 21.02 & 20.36 & 20.44 & 20.45 & 20.31 & 20.39 & 16.62 \\
\hline Botrytis & 19.63 & $19.39 * * *$ & 20.45 & 20.13 & $19.80 *$ & 19.91 & 20.12 & 18.04 \\
\hline \multicolumn{9}{|l|}{$\mathbf{E T}_{690}$} \\
\hline Control & 16.83 & 17.05 & 16.98 & 17.09 & 18.49 & 18.38 & 18.19 & 17.85 \\
\hline Botrytis & $15.25 * * *$ & $14.56 * * *$ & 16.81 & 15.42 & 17.47 * & $17.09 * *$ & 17.72 & 16.42 \\
\hline \multicolumn{9}{|l|}{$\mathbf{E T}_{740}$} \\
\hline Control & 21.14 & 21.17 & 20.18 & 20.41 & 20.93 & 20.72 & 20.71 & 19.42 \\
\hline Botrytis & 16.23 & $19.20 * * *$ & 20.58 & 19.07 & 20.75 & 20.41 & 20.26 & 17.34 \\
\hline
\end{tabular}

Where $\quad$ DAI=Days after inoculation

$*, * *, * *=$ significant at $\mathrm{p} \leq 0.1,0.05,0.01$ 
Author-produced version of the article published in International Journal of Remote Sensing, 2011, 32 (14),3835-3849. The original publicatioin is available at http://www.tandfonline.com doi:10.1080/01431161003782064

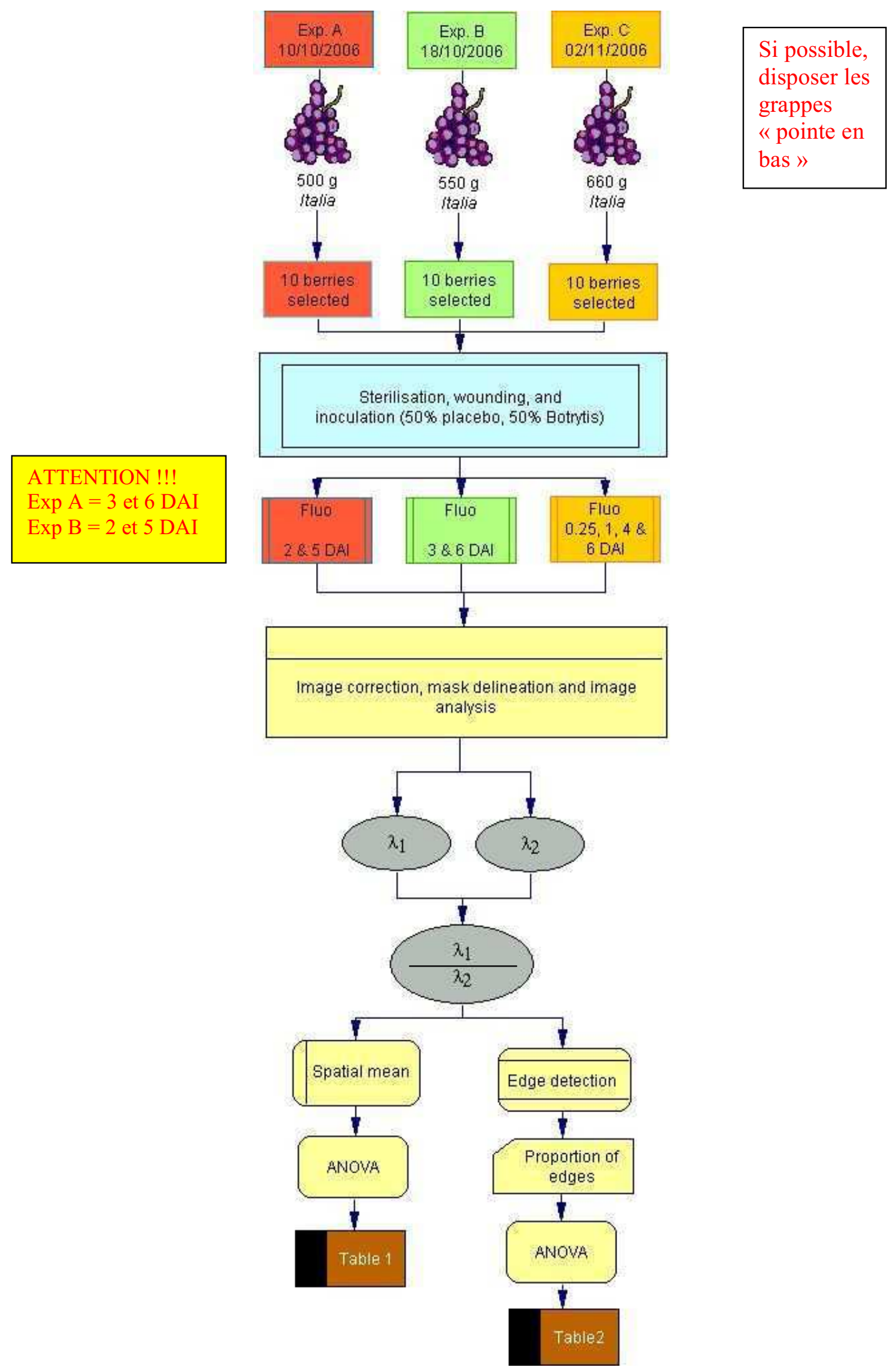

Fig. 1 Schematic representation of methodology and data analysis 
Author-produced version of the article published in International Journal of Remote Sensing, 2011, 32 (14),3835-3849.

The original publicatioin is available at http://www.tandfonline.com doi:10.1080/01431161003782064

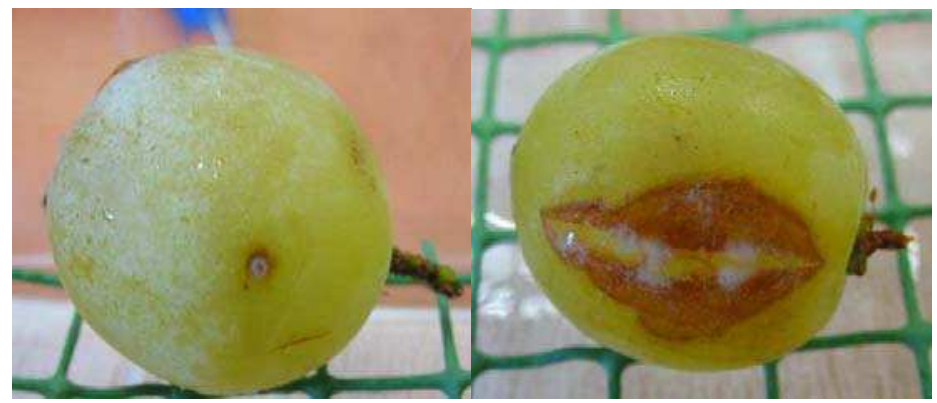

Figure 2 : Digital picture of control berries (left) and botrytised berries (right)

Exp. A, 6 DAI 
Author-produced version of the article published in International Journal of Remote Sensing, 2011, 32 (14),3835-3849.

The original publicatioin is available at http://www.tandfonline.com doi:10.1080/01431161003782064

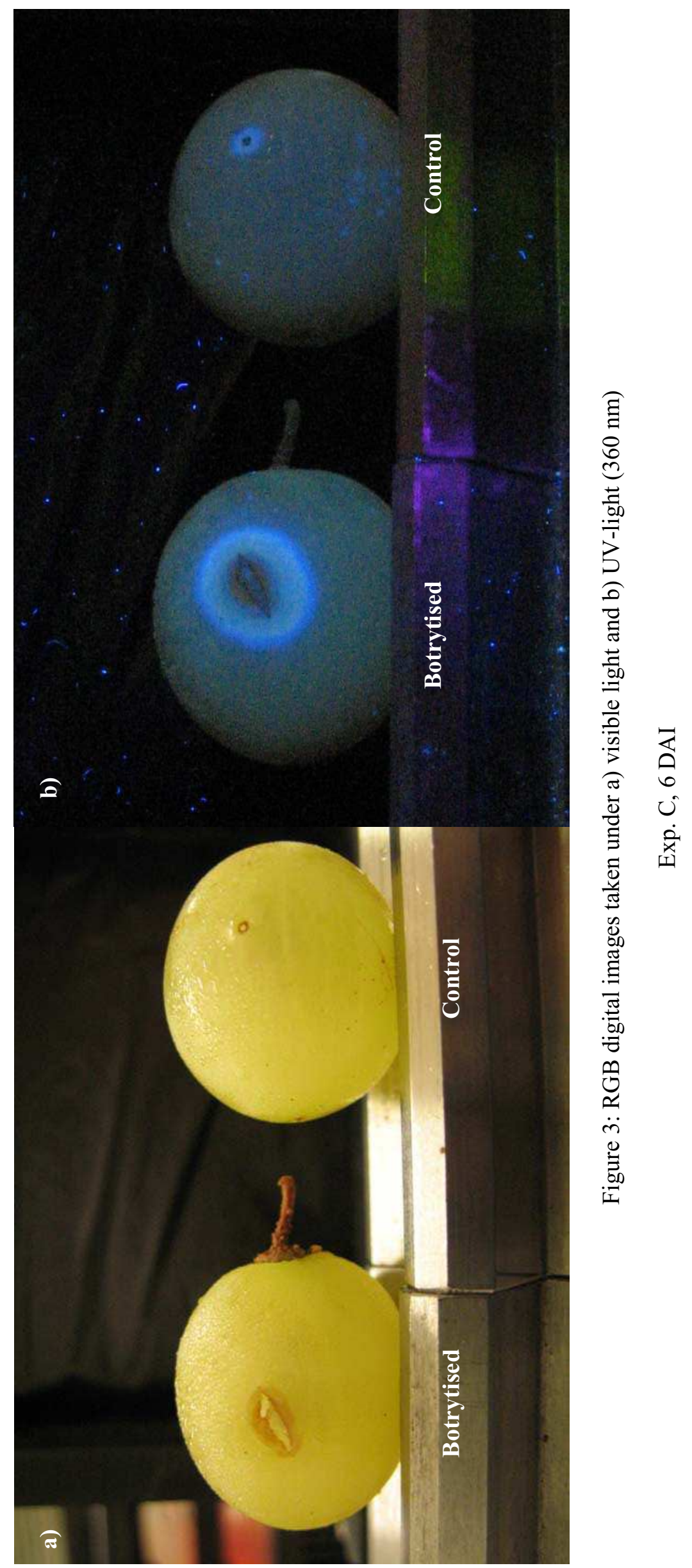




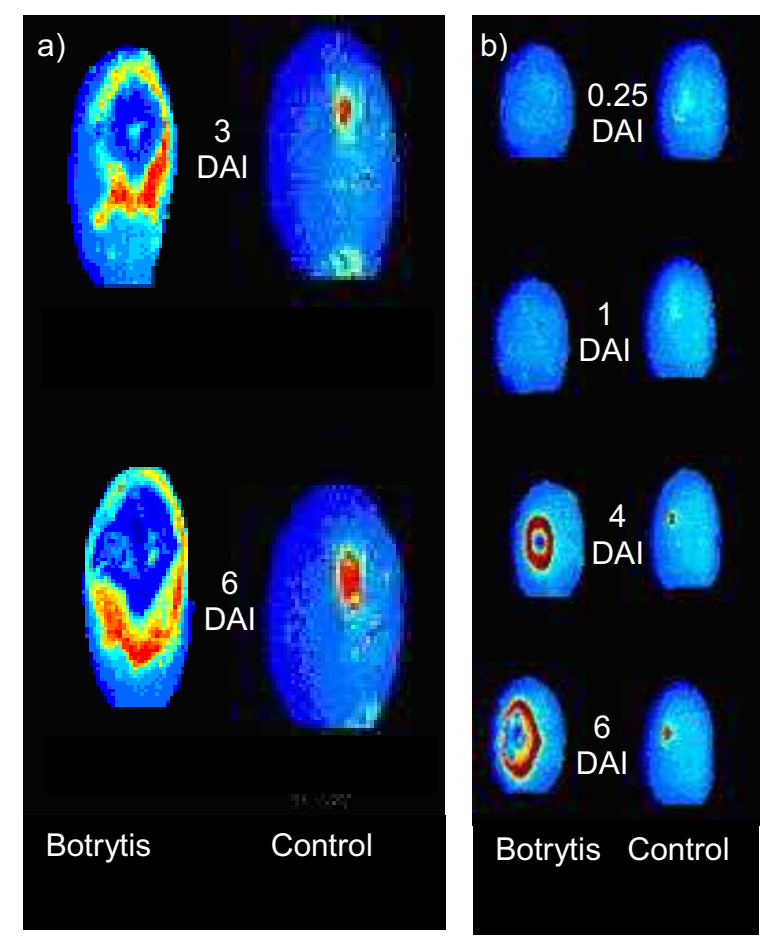

Figure 4: UV-induced fluorescence images taken at $440 \mathrm{~nm}$ on a) experiment A botrytised and control berries, at 3 DAI and 6 DAI and b) experiment $\mathrm{C}$ botrytised and control berries, at $0.25,1,4$ DAI and 6 DAI. 
Author-produced version of the article published in International Journal of Remote Sensing, 2011, 32 (14),3835-3849.

The original publicatioin is available at http://www.tandfonline.com doi:10.1080/01431161003782064
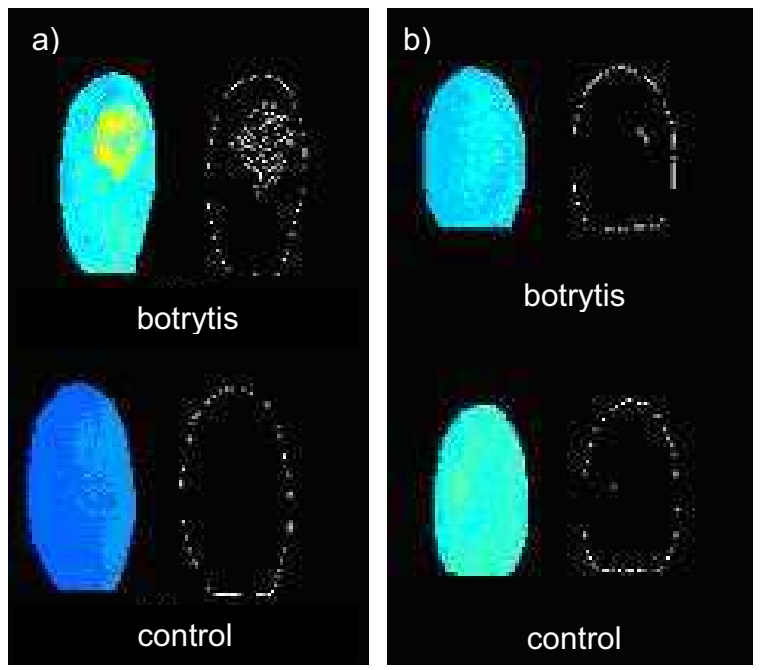

Figure 5 : ET690 fluorescence images and edges detected for each experiment, on the earliest dates of measurements a) Exp A 3 DAI b) Exp C, 0.25 DAI. 
Author-produced version of the article published in International Journal of Remote Sensing, 2011, 32 (14),3835-3849.

The original publicatioin is available at http://www.tandfonline.com doi:10.1080/01431161003782064

[U1] Nous ne comprenons pas comment une diminution de la mesure se traduit par une visualisation accrue du phénomène de fluorescence sur la fig. 5 (Peux tu éclairer notre lanterne ?)

[U2]A nouveau, c'est une diminution des chiffres qui est constatée dans le tableau 2, mais l'explication qui suit tient elle alors toujours?

[U3]To get to ? N'y aurait il pas un autre verbe biologique plus adapté ? « enabling chlorophyll to be excited by UV radiations?

[U4]Tab à uniformiser avec tab. 1 (voir mes précédents commentaires) 